\title{
Extraterritorial osteoclast traits of primary cancer cells
}

Henning M. Schramm

Society for Cancer Research, Institute Hiscia, 4144 Arlesheim/Switzerland. E-mail: h.schramm@vfk.ch

Received: $2011-07-07$

Accepted: $2011-08-28$

Published: $2011-10-20$

DOI : 10.5430/jst.v1n2p65

URL: http://dx.doi.org/10.5430/jst.v1n2p65

\begin{abstract}
Cancer cells seem to originate in the epithelium however the majority of their phenotypic functions and traits do not resemble an epithelian but a preosteoclast/osteoclast cell. This applies not only to bone metastases but also the primary tumor, where these characteristics are exhibited extraterritorially. The most remarkable common features between osteoclasts and cancer cells include, among many others, matrix-resolving properties, hormone and neuronal dependence, coupling with mesenchymal cells, migrating and transmigrating properties, neurogenetic activities, trafficking to the bone, immune deviation, sensitivity to antirheumatics, bisphosphonates, polyphenols and steroids, constitutive activation of NFkappaB, and the same cytokine and chemokine signalling pathways. Below we present the corresponding findings reported in scientific publications and discuss various aspects of this congruency between cancer cells and preosteoclasts/osteoclasts.
\end{abstract}

\section{Key words:}

Cancer cells; Osteoclasts; Mesenchymal cells; Phenotypic properties; Signaling pathways

\section{NTRODUCTI ON}

Cancer cells start to proliferate within epithelial cells, and they seem to originate here with their cytokeratin scaffold. However, many of their traits are more similar to the cells of macrophage/monocyte lineage than to epithelial cells. To explain this peculiar feature of cancer cells, Pawelek and others proposed that cancer cells coopt macrophage traits through macrophage-tumor cell fusions. ${ }^{1}$ In our previous studies we investigated why no primary carcinoma had been detected in the auditory inner ear in various large clinical studies on inner-ear tumors. As the development of preosteoclast lineage is inhibited in the auditory inner ear, we raised the question of whether these cells are required for "malignant transformation of epithelial cells". ${ }^{2}$ In order to examine this question in more detail, we here compare the traits of cancer cells with those of preosteoclast lineage.

Both cell types, macrophages and preosteoclasts, originate from the same progenitor cell; it is therefore not surprising that the macrophages already share many traits with cancer cells. However, some important traits are not shared, such as coupling with mesenchymal cells or sensitivity to antirheumatics, bisphosphonates, polyphenols and other substances and the common receptor for osteocalcin - not expressed by macrophages.

Cancer cells and preosteoclasts differ in one decisive respect: that the former may proliferate limitlessly whereas the preosteoclast cells fuse with each other to form multinucleated giant cells. Assuming as a hypothesis that both cells may originate from a common progenitor cell, the question arises whether a common prerequisite may underlie these two 
different processes. Before we discuss this question, we will compare the various features of cancer cells with those of preosteoclasts, and focus our review on aspects which seem to be common key features of cancer and bone remodelling.

\section{Common traits between cancer cells and osteoclasts}

Cancer cells may show hormonal, neuronal, metabolic and immunological interactions, require mesenchymal coupling for their growth, have extreme matrix-dissolving capacities by secreting metalloproteinases, are endowed with extreme plasticity and are sensitive to antirheumatics, bisphosphanates and polyphenols. These typical features also apply to osteoclasts as we will demonstrate in this review. A wide diversity of molecules and signalling pathways regulating adhesion, matrix alteration, neoangiogenesis, motility, chemotaxis, immune signalling, and multidrug resistance proteins, are traits we detect in cancer cells as well as in preosteoclasts. Several publications describe the osteomimetic properties of metastasizing prostate and breast cancer cells. ${ }^{3-5}$ To our knowledge, the finding that primary cancer cells already show a large spectrum of different osteoclast aspects - with scaffold and proliferation as exceptions - has not so far been reviewed and investigated.

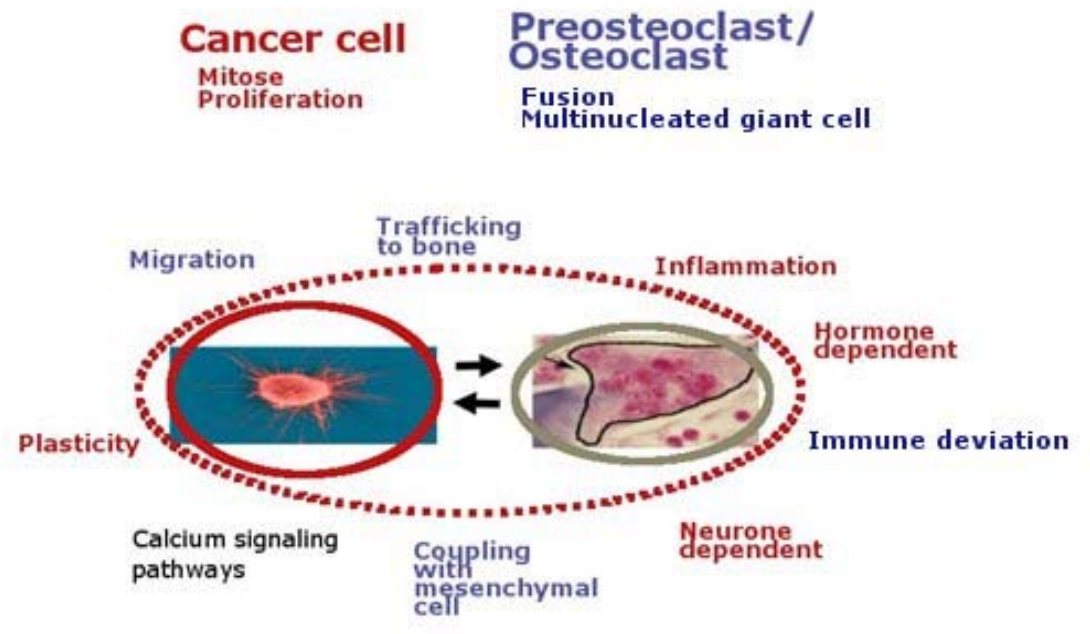

Figure 1 Common traits - around the oval circle - and divergent features - under the cell names - between a cancer cell and a preosteoclast/osteoclast

\section{Migration \\ Trafficking to the bone}

The migration of cancer cell, and of preosteoclast, are very reminiscent of each other. ${ }^{6}$ Cancer cells and osteoclasts show the same extraordinary and unusual ability to migrate and transmigrate through cell layers and tissues in order to reach the skeleton. Although nearly all cancers may frequently metastasize to the bone, the commonest malignant tumors have a special predilection for the skeleton. In particular, cancers of breast, prostate, thyroid, kidney, rectum, uterus, cervix, bladder and lung frequently metastasize to the skeleton. The epithelial cancer cell transforms itself into a mesenchymal-like cell and gains extreme capacities to migrate through layers and tissues in order to reach its target. ${ }^{7}$ When becoming committed to the osteoclast lineage, monocytes in the peripheral blood, and perhaps in inflamed areas, traffick to the bone in the same way, but there fuse with their equals. ${ }^{6}$

The trafficking of cancer cells and osteoclasts to bone involves many factors, among them chemo-attractants such as SDF-1(CXL-12) /CXCR4 axis, MCP-1, transcription factors such as NFkappaB and STAT3, cytokines such as RANK/RANKL and Il-6, hormones such as osteocalcin, oestrogen and androgens, further neurotransmitters, alphaVbeta3 integrins/ osteopontin, and calcium signalling pathways. ${ }^{6}$ 


\section{Migrating and transmigrating properties}

Osteoclast precursors, like cancer cells, are able to cross the endothelial layer of blood capillaries and other basement membranes. Both cell types show mesenchymal as well as amoeboid migration. ${ }^{7}$ In cancer cells as in osteoclasts, dynamic actin remodelling appears to be one major factor endowing these cells with their migrating property. During transmigration, integrin alphaVbeta3 is expressed around actin patches in cancer cells as in osteoclast precursors. ${ }^{6}$ Matrix metalloproteinases (MMPs), secreted at the podosomes site, are required for the degradation of the extracellular matrix; and this contributes to the invasiveness of cancer cells. The same function facilitates the migration of osteoclasts through barriers, to form pits in the bone. ${ }^{8}$

\section{The roles of the Chemokine receptor CXCR4 - chemokine SDF-1 (CXCL12) axis in cancer cells and in osteogenesis}

The chemokine receptor-chemokine axis CXCR4/SDF-1 plays multiple roles in tumor pathogenesis ${ }^{9}$ as well as in osteogenesis. ${ }^{8}$ The tumor cells crosstalk with tumor-associated fibroblasts as do osteoclasts with osteoblasts via the chemokine axis CXCR4/SDF-1.

CXCR4/SDF-1 signalling is active in all cancer cells studied including rhabdomyosarcomas, prostate, kidney, melanoma, ovarian, endometrial cancer cells, multiple myeloma, plasma cells, nasopharyngeal carcinoma and brain tumors. ${ }^{10,11}$ CXCL12 (SDF-1) is released by cancer-associated fibroblasts under a variety of conditions and promotes the malignancy of tumor cells. ${ }^{12}$ The chemokine is important for the growth, angiogenesis, survival and trafficking to bone of malignant cells. ${ }^{13}$ HER2 enhances the expression of CXCR4 in breast cancer cells. ${ }^{14}$ It contributes to immunesuppressive networks within the tumor environment. ${ }^{15}$

Circulating osteoclast precursors react via their chemokine receptor CXCR4 to its ligand SDF1 produced by bone endothelium, bone marrow stromal cells and especially by osteoblasts. SDF1 stimulates matrix metalloproteinase-9 activity in the osteoclast precursors and enhances their directional migration through the collagen. It further initiates their differentiation into mature osteoclasts in cooperation with RANKL and other cytokines.

\section{Matrix dissolving properties (tissue invasion and metastases): MMPs and Cathepsin K}

MMPs and cathepsin are excreted by a variety of cells, among them cancer cells and osteoclasts. As proteases both possess matrix-resolving properties. These proteases are expressed in nearly all tumors including inflammatory cells contributing to tumorgenesis, and stimulate tumor growth, invasion, migration and metastasis. ${ }^{16-19}$

MMP-9 and MMP-2 secretion plays an important role during migration of the preosteoclast, and is necessary for the initiation of bone pit resorption. Especially during differentiation into osteoclast, MMP-9 excretion is increased. ${ }^{8}$

Cathepsins are members of the lysomal cysteine proteases family. Cathepsin $\mathrm{K}$ is overexpressed by cancer cells and cancer-associated fibroblasts. ${ }^{20}$ Cancer patients with adenocarcinomas and squamous cell carcinomas of the lung, and carcinomas of breast and prostate, with high cathepsin K expression, showed a reduced overall survival. Stromal cathepsin $\mathrm{K}$ expression was significantly higher in invasive cancer compared with in-situ carcinomas, and thus correlated with higher tumor stage. In some cancer models, and in breast cancer biopsies, cathepsin K could not be detected in the neoplastic cells, but was found in the tumor's stromal cells. ${ }^{18}$

Cathepsin $\mathrm{K}$ is highly expressed in osteoclasts and plays an essential role in bone remodelling as shown by the osteopetrotic phenotype of cathepsin-deficient mice. ${ }^{18}$ Overexpression of cathepsin $\mathrm{K}$ in osteoclasts results in enhanced bone resorption.

\section{Neurogenesis and neuronal dependency}

Bone remodelling, like most other homeostatic functions, but also carcinogenesis, cancer progression and metastasizing capacities, is subject to sympathetic influence. $70 \%$ to $90 \%$ of breast, colon, gastric, lung, ovarian, nasopharyngeal and prostate cancer tissues express beta2-adrenergic receptors. The migration of breast, prostate, ovary and colon carcinoma cells is enhanced by the stress-related neurotransmitter norepinephrine, and this effect can be inhibited by the betablocker propranolol. ${ }^{21}$ 
Both osteoblasts and osteoclastic cells are equipped with adrenergic receptors and neuropeptid receptors. ${ }^{22}$ Sympathetic neurons in the hypothalamus and bone control osteoblast activity in bone formation, and osteoclast activity in bone resorption via beta2-adrenergic receptors. ${ }^{23}$ Beta-adrenergic agonists, and adrenaline and isoprenaline, modulate osteoclastogenesis. Increased sympathetic nervous system activity leads to increased bone resorption through beta2adrenergic receptors. $^{23}$

Osteoblastic and osteoclastic cells on the one hand, and cancer cells on the other, constitutively express diffusible axon guidance molecules such as netrins and neurotrophins, which are known to function as chemoattractants for growing nerve fibres. ${ }^{24,25}$

\section{Hormone dependence}

Osteoclasts and many cancer cells are hormone responsive. Steroid hormones and other hormones such as osteocalcin, calcitonin and IGF-1 are crucial regulators of cancer disease as well as bone remodelling.

\section{Oestrogens and androgens}

Cancer growth and malignancy on the one hand, and bone remodelling on the other, are influenced by hormones e.g. sex steroids such as oestrogens and androgens.

In breast cancer, oestrogen-receptor status is a key factor for prognosis and treatment. Breast cancer cells also can express androgen receptors and this seems to be connected with tumor metastasis. ${ }^{26}$ Cancer sites other than the breast express the oestrogen steroid receptors as well, demonstrated specifically in cancers of lung, oesophagus, stomach, colon, gynaecological organs, testes and in glioma. In lung cancers it has been shown that the membrane oestrogen receptors can transactivate the EGFR. ${ }^{27}$ Increased serum oestrogen is associated with poorer survival among male and female lung-cancer patients. ${ }^{28}$

The androgen steroid receptor plays an important role in the course and treatment of prostate cancer.

Sex steroids are important for the growth and maintenance of both the female and the male skeleton. ${ }^{29}$ Experiments using mice with inactivated sex steroid receptors demonstrated that activation of the oestrogen receptor alpha expressed by osteoclasts, and activation of the androgen receptor, both result in stimulatory effects on both the cortical and trabecular bone mass in males. Oestrogens and androgens exert pro-apoptotic effects on osteoclasts, but anti-apoptotic effects on osteoblasts and osteocytes, and decrease the number of remodelling cycles by attenuating the birthrate of osteoclasts and osteoblasts from their respective progenitors. Loss of oestrogen leads to increased rate of remodelling, and tilts the balance between bone resorption and formation in favour of the former.

Tamoxifen inhibits differentiation of osteoclasts and proliferation of cancer cells. ${ }^{30}$

\section{GF-1}

IGF-1 (Insulin-like growth factor 1) is a polypeptide and plays a key role in bone remodelling as well as in cancer progression.

IGF-1 is implicated in the proliferation of many types of cancers such as pancreas, prostate, mammary, and colorectal carcinoma. Mouse models where circulating IGF-1 levels are reduced, while tissue expression of IGF-1 is normal, show lower risk for the development of colon and breast cancer and metastases when compared to control mice ${ }^{31}$. Patients with Laron syndrome (inactive GH receptor resulting in IGF-1 deficiency) seem to be protected from cancer ${ }^{32,33}$. In in-vitro tests, upon withdrawal of IGF-1 from the medium, cancer cells revert to an epithelial morphology. IGF-1 plays an important role in EMT, whereby epithelial cancer cells gain motility and the propensity to migrate. ${ }^{34,35}$

IGF-1 is an important regulator of the activity between preosteoclasts and mature osteoblasts through the regulation of RANKL and RANK expression between osteoclasts and osteoblasts. ${ }^{36}$ IGF-1 deficiency has been found to impair osteoclastogenesis, resulting in decreased bone resorption. ${ }^{37}$ It plays a paracrine role in the recruitment of circulating preosteoclasts from the vascular compartment into the bone tissue. IGF-1 receptors are expressed by osteoclast precursors. Through binding with their IGF-1 receptors, IGF-1 induces the migration of preosteoclasts. 


\section{Calcium signalling Osteopontin/ CD44/ integrin alphaVbeta3}

Osteopontin is produced by cancer cells, in the same way that it is produced by osteoblasts and osteoclasts. Osteopontin is one of the major noncollagenous bone matrix proteins and is overexpressed by various cancers. ${ }^{38}$ It binds to osteoclasts or cancer cells via CD44 or/and integrin alphaVbeta3. Among other things, its signalling plays an important role in the motility of both cancer cells and osteoclasts.

Osteopontin-integrin alphaVbeta3 signalling mediates CD44/MMP-9 complex formation on the cell surface and enhances survival in gastrointestinal and other cancer cells. ${ }^{38,39}$ It is involved in MMP-9 secretion and migrating motility. Thus the expression level of osteopontin correlates with the metastatic potential of several cancer tumors.

In bone remodelling, osteopontin together with receptor alphaVbeta3, promotes cell adhesion of osteoclasts and chemotaxis during bone resorption. Osteoclasts deficient in osteopontin were found to be hypomotile, and exhibited decreased capacity for bone resorption in vitro.

\section{Calcitonin-Calcitonin Receptor axis}

Calcitonin is a small neuropeptide hormone produced in the thyreoidea, and counteracts the activity of parathyroid hormone. Both hormones regulate calcium and phosphate metabolism in the organism. Calcitonin is secreted in response to hypercalcaemia. The calcitonin receptor, along with TRAP, are specific osteoclast markers. ${ }^{40}$ Calcitonin is not expressed by macrophages. ${ }^{41,42}$ Besides the role of calcitonin in bone remodelling through inhibiting the bone resorbing activity of osteoclasts, it exerts decisive effects on cancer as demonstrated with prostate and breast cancer cells. In animal studies, calcitonin inhibited invasion of breast cancer cells and suppressed ERK1/2 phosphorylation. ${ }^{43}$ However, in prostate cancer cells it seems to exert an opposite effect. It is produced by prostate cancer cells to a certain level for autocrine and paracrine stimulation of growth and invasiveness. ${ }^{44}$

\section{Parathyroid hormone-related peptides (PTHrP)}

PTHrP is an ubiquitously expressed protein playing important roles in various signalling pathways of cells and, among other things, is involved in epithelial-mesenchymal interaction during the formation of the mammary gland. In bone remodelling it acts between osteoclasts and osteoblasts, and under pathological conditions it is an essential growth factor for various cancers.

During tumor growth and invasion a number of growth and also angiogenic factors - such as interleukins, tumor-derived growth factor beta, platelet-derived growth factor and vascular endothelial-derived growth factor - modulate its expression. ${ }^{45}$ Parathyroid hormone-related peptides are the responsible factor for hypercalcaemia associated with malignancy. ${ }^{46}$ Most malignant human tumors express this hormone abundantly, however only in some tumors does this result in hypercalcaemia. ${ }^{45}$ PHTrP might be related to heterotopic ossification associated with malignancies. ${ }^{47}$

PTHrP also functions as a bone cytokine to control the bone mass. ${ }^{48}$ Osteoblasts produce PTHrP very early during their differentiation, and activate PTHrPR1 of mature osteoblasts to produce RANKL. This growth factor exerts a paracrine role in osteoclast formation. ${ }^{49}$ A direct effect of PTHrP on osteoclasts cannot be excluded either, as osteoclasts express the PTHR-1. Whether osteoclasts or their precursors also express PTHrP acting in an autocrine manner, has so far not been clearly demonstrated. In giant cell granulomas the preosteoclasts express PTHrP as well as PTHR1. ${ }^{50}$

\section{Osteocalcin}

Osteocalcin is a small peptid hormone, which plays an important role in the remodelling of bone as well as in cancer progression.

Osteocalcin has been detected in prostate, breast, lung and pancreas carcinoma as well melanoma. Osteocalcin expressed in pancreatic cancer cell lines was found to enhance cell growth and invasion through autocrine and paracrine mechanisms. ${ }^{51}$ Most studies on osteocalcin's role in cancer involved prostate and breast cancer. Osteocalcin RNA is highly expressed in most prostate cancer cells regardless of the tumor's metastatic status. ${ }^{52}$ Elevated osteocalcin protein levels in the serum are found in metastatic prostate and breast cancer compared to non-metastatic patients. ${ }^{52,53}$ 
Osteocalcin is synthesized and secreted by normal maturing osteoblasts and acts as a bone hormone. Osteocalcin when carboxylated by vitamin $\mathrm{K}$ ensures the outfall of calciumphosphate in the bone while preventing it elsewhere in the organism. It regulates the dynamics of new bone formation and bone resorption by interaction with vitamin $\mathrm{D}$ and by influencing the differentiation of osteoblasts. As a chemoattractant it plays an important role in the migration of osteoclast precursors to the bone surface. ${ }^{54}$ In a further function, osteocalcin acts as a hormone on insulin secretion and utilization. ${ }^{55}$

\section{Coupling between cancer cells and mesenchymal cells, and between osteoclasts and mesenchymal cells}

Both cancer cells and osteoclasts are coupled to mesenchymal cells and need them for their growth, differentiation and survival. Cancer cells are coupled to the mesenchymal tumor-associated fibroblast, and similarly osteoclasts are spliced to mesenchymal osteoblast.

In the tumor, the cancer cells are constantly interacting with tumor-associated stromal cells. The latter are not just bystanders in the tumor region, but contribute to tumor progression and metastasizing capacity. ${ }^{12}$ The cancer cell releases factors that enhance the ability of the fibroblast to secrete a variety of tumor-promoting chemokines. Chemokines are involved in these processes: chiefly the CXCL12-CXCR4 axis, ${ }^{9}$ Rankl-Rank, ephrinB2-EphB4, PTHrP-type 1- PTH receptor.

The importance of cancer-associated fibroblasts in epithelial carcinogenesis has been established in combination experiments. When immortalized nontumorigenic human prostate epithelial cells were mixed with fibroblasts from human prostate carcinomas grafted to immune-deficient animals, the epithelial cells developed into large carcinomas. In contrast, mixing the epithelial cells with fibroblasts from a normal prostate gland did not result in carcinomas. ${ }^{56}$

Parts of the stromal cells originate in the host's bone marrow. Primary tumors are able to encourage mobilization and recruitment of fibroblast precursors from the bone marrow, indicating that such tumors interact with the bone marrow in order to promote their own proliferation.

A similar situation exists between the preosteoclast and the osteoblast. They likewise communicate via these chemokines, through cell-cell contact, diffusible paracrine factors and cell-bone matrix interaction. ${ }^{49}$ The osteoclasts are dependent on this crosstalk for their differentiation. ${ }^{49}$

\section{RANK-RANKL}

RANK-RANKL belongs as a cytokine system to the family of tumor-necrosis factors involved in osteoclastogenesis and cancer progression.

Analysis of surgical biopsy specimens showed the expression of RANKL, RANK and OPG in primary carcinomas, specifically lung, breast, head and neck, colorectum, kidney, thyreoidea and liver. The median percentage of RANKLexpressing cells was $60 \%$ in primary tumors and metastases, with no statistically significant difference between the two groups. ${ }^{57}$ This study highlights the activity and function of the RANKL-RANK system not only in bone metastasis management but also in primary tumors. The expression of RANKL is associated with epithelial to mesenchymal transition as shown in human prostate cancer cell lines. Besides their own production of RANKL, cancer cells - like osteoclasts - can stimulate osteoblasts to secrete RANKL.

RANK is the essential signalling receptor for the osteoclast-differentiation factor in osteoclastogenesis. The binding of RANKL, expressed by osteoblast, with RANK receptor expressed by immature osteoclasts, stimulates their differentiation into multinucleated mature osteoclasts. ${ }^{49}$

\section{I nflammatory context}

\section{Constitutive activation of NFkappaB and Stat3}

Two major transcription factors, namely NFkappaB and STAT3, play a major role in transmitting inflammatory cytokine signals to the nucleus. Constitutive NFkappaB and STAT3 activation has been observed in about $40 \%$ of the 
tissue specimens of various cancer sites. The transcription factors may be involved in tumor initiation, angiogenesis and invasiveness. ${ }^{58,59}$

STAT3 and NFkappaB are also a prerequisite for the maturation of preosteoclasts into osteoclasts, and consequently the inhibition of NFkappaB activity blocks the differentiation of preosteoclasts into osteoclasts. NFkappaB induces the RANKL expression of osteoblasts. ${ }^{60}$ The constitutive activation of NFkappaB is also a prerequisite for MMPs secretion and thus for the bone-resolving capacities of osteoclasts. ${ }^{61}$ STAT3 activation is required in this context as well. ${ }^{62}$

\section{MCP-1}

Besides its production by macrophages, fibroblasts and endothelial cells, monocyte chemoattractant protein 1 (MCP-1 or CCL2) is secreted by both cancer cells and osteoclasts. MCP-1 plays a critical role in the recruitment and activation of monocytes to sites of inflammation, injury and cancer as well as in bone remodelling. ${ }^{63}$ In the latter it is involved in the receptor activator of NF-kappa ligand-induced fusion of preosteoclasts and enhances osteoclastogenesis. ${ }^{64}$ In several cancers, MCP-1 has been shown to be an important factor for tumor growth and migration. ${ }^{63}$

\section{Sensitivity to antirheumatics, steroids, bisphosphonates and polyphenols}

Both cancer cells and osteoclasts are inhibited by antirheumatics, vitamin D, ${ }^{65,66}$ bisphosphonates and polyphenols. The antirheumatic and analgetic substance aspirin inhibits the transformation of a benign tumor into malignant one. In-vitro studies with various antirheumatics show that they inhibit growth and proliferation of cancer cells. ${ }^{67}$

Bisphosphonates not only inhibit osteoclastogenesis, but also show direct anti-tumor effects on cancer cells. ${ }^{68}$

Numerous in-vitro and some in-vivo studies demonstrate that polyphenols, a substance class found in various plants, show direct antitumoral activity ${ }^{69}$ as well as inhibition of osteoclastogenesis. ${ }^{70}$

\section{Glycolysis}

Proliferating cancer cells and preosteoclasts in differentiation show an increased level of glycolysis. Local hypoxia stimulates the aggressiveness of cancer cells and activates osteoclastogenesis, both under the control of HIFalpha1. Intermittant hypoxia specifically increases cancer cell migration, spontaneous metastasis formation, and osteoclastic activity.

Tumors generally show a shift in their metabolism from oxidative phosphorylation to glycolysis and thus exhibit increased glycolysis for ATP generation. ${ }^{71}$ Cancers frequently rely less on mitochondria and obtain as much as $50 \%$ of their ATP by metabolizing glucose directly to lactic acid, even in the presence of oxygen. ${ }^{72}$ Increased glycolysis induces acidification of the local environment, limiting proliferation and inducing cell death through necrosis and apoptosis. ${ }^{73}$

The role of glycolysis in osteoclast precursors and osteoclasts has not been studied to the same extent as in cancer cells. Preosteoclasts show a metabolic switch to accelerated glycolysis and mitochondrial respiration during RANKLstimulated osteoclast differentiation. ${ }^{71}$ Various studies were done with monocytes. As monocytes can transform into osteoclasts and may represent potential osteoclast precursors, we include them here. In particular, monocytes, and among them preosteoclasts, migrate through areas widely varying in oxygen tensions. Activated monocytes increase their energy gain through glycolysis even in the presence of enough oxygen, thus anticipating hypoxia and therefore better adaptation to low oxygen conditions in the tissue potentially arising in inflammation or ischaemia. ${ }^{74}$ This results in prolonged survival under hypoxia in comparison to other cells and this is most likely due to increased glycolysis. ${ }^{74}$

\section{I mmune deviation}

A still unresolved issue surrounding tumor formation involves the role of immune deviation. The hypothesis is that solid tumors suppress detection by various arms of the immune system, thereby evading eradication. For example cancer cells may paralyze immune cells by secreting TGF-beta or other immunosuppressive factors like interleukine-10. ${ }^{75}$ On the other hand certain immune inflammatory process may even enhance tumor progression. ${ }^{75}$

Intensive interactions also take place between the immune system and osteoclasts. Bone cells are subject to the influence of immune cells. Activated T-cells enhance osteoclastic acitivity and their differentiation. This may lead to osteoporosis. On the other hand osteoclasts may induce immune suppression through the same cytokines as secreted by cancer cells 
e.g. TFG-beta and interleukin-10 as shown in-vitro and in animal models. ${ }^{76-79}$ Osteoclast can recruit T-cells and regulate them in a feedback loop. ${ }^{77}$

\section{SCUSSI ON}

Most researchers try to understand the pathogenesis of cancer by investigating single cellular mechanisms or communication pathways within or among the cells in the context of a genetic or mutational concept. Here we choose another approach and offer a comparison of conceptual structures by compiling these single cancer findings on the one hand, and corresponding features of osteoclasts and osteoblasts on the other. This comparison shows that at the cellular and signalling pathway level there are more shared phenotypical aspects between cancer cells and preosteoclasts than between cancer cells and epithelial cells. Cancer cells seem to be more strongly related to preosteoclasts than to epithelial cells. The comparison can lead to various hypotheses to explain these exterritorial traits of cancer cells. It

Table 1 Examples of preosteoclast traits expressed by cancer cells

\begin{tabular}{|c|c|c|}
\hline $\begin{array}{l}\text { Common traits between cancer cells and } \\
\text { preosteoclasts/osteoclasts }\end{array}$ & $\begin{array}{l}\text { Common signalling pathways in cancer and in } \\
\text { bone remodelling }\end{array}$ & $\begin{array}{l}\left.\text { Reference ( } c^{*} \text { and } o^{*}\right) \text { and } \\
\text { comments/references }\end{array}$ \\
\hline $\begin{array}{l}\text { Amoeboid or mesenchymal single-cell } \\
\text { motilities; Migration, transmigration }\end{array}$ & $\begin{array}{l}\text { Actin cytoskeleton; dynamic actin remodelling; } \\
\text { RANK-RANKL; SDF-1/CXCR4; NFkappaB; Rac } \\
\text { and Rho GTPase }\end{array}$ & {$[7]^{\mathrm{C}}[80]^{\mathrm{O}}$} \\
\hline Trafficking to bone & SDF-1/CXCR4 & {$[81]^{\mathrm{C}}[15]^{\mathrm{c}}[13]^{\mathrm{C}}[82]^{\mathrm{o}}$} \\
\hline $\begin{array}{l}\text { Chemotaxis, chemokines, chemokine } \\
\text { receptors }\end{array}$ & SDF-1/CXCR4; CCL9/MIP-1/CCR1 & {$[81]^{\mathrm{C}}[11]^{\mathrm{c}}[82]^{\mathrm{o}}$} \\
\hline Angiogenesis & VEGFs angiogenic factors & {$[83]^{\mathrm{oc}}$} \\
\hline Neuronal dependence & Alpha2 adrenergig signalling & {$[21]^{\mathrm{C}}[22]^{\mathrm{O}}[23]^{\mathrm{O}}$} \\
\hline Neurogenesis & Neurothrophin and neurotrophin receptors; VEGFs & {$[25]^{\mathrm{C}}[24]^{\mathrm{O}}$} \\
\hline $\begin{array}{l}\text { Coupling and interaction with mesenchymal } \\
\text { cells }\end{array}$ & $\begin{array}{l}\text { RANK-RANKL; with fibroblast, myofibroblast; } \\
\text { osteoblasts }\end{array}$ & {$[9]^{\mathrm{C}}[12]^{\mathrm{C}}[56]^{\mathrm{C}}[49]^{\mathrm{O}}$} \\
\hline Growth factors & EGF/EGFR; HGF/Met; IGF-1/ IGF-1R & {$[32]^{\mathrm{C}}[84]^{\mathrm{C}}[33]^{\mathrm{O}}[37]^{\mathrm{o}}$} \\
\hline Adhesion & Integrins alphaVbeta3 & {$[39]^{\mathrm{C}}[6]^{\mathrm{O}}$} \\
\hline Matrix-dissolving properties, aggressiveness & MMPs, cathepsins & {$[18]^{\mathrm{C}}[8]^{\mathrm{O}}[16]^{\mathrm{O}}$} \\
\hline $\begin{array}{l}\text { Overexpressed signalling pathways of } \\
\text { proliferation and anti-apoptosis }\end{array}$ & $\begin{array}{l}\text { Ras/ERK; AKT; MAPK; } \\
\text { Runx2 }\end{array}$ & {$[35]^{\mathrm{C}}[85]^{\mathrm{co}}[86]^{\mathrm{O}}[87]^{\mathrm{o}}$} \\
\hline Hormonal dependence & Steroid homones, oestrogens/ androgens & $\begin{array}{l}{[27]^{\mathrm{C}} \text { Olivo-Marston, } 2010} \\
\# 37]^{\mathrm{C}}[26]^{\mathrm{C}}[30]^{\mathrm{o}}[88]^{\mathrm{O}}[\end{array}$ \\
\hline Glycolysis & IGF-1 & {$[73]^{\mathrm{C}}[31]^{\mathrm{C}}[72]^{\mathrm{C}}[71]^{\mathrm{O}}[74]^{\mathrm{o}}$} \\
\hline Mesenchymal-like differentiation/plasticity & EMT; MET & {$[34]^{\mathrm{C}}[89]^{\mathrm{O}}$} \\
\hline Scaffold & Cytokeratin; vimentin; actin & {$[90]^{\mathrm{co}}[91]^{\mathrm{co}}[92]^{\mathrm{co}}$} \\
\hline Inflammatory signalling pathways & NFkappaB, STAT3 & 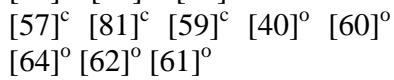 \\
\hline Calcium signalling & $\begin{array}{l}\text { Osteocalcin, calcitonin, } \\
\text { Parathyroid hormon-like peptide; osteopontin }\end{array}$ & $\begin{array}{l}{[52]^{\mathrm{c}}[43]^{\mathrm{c}}[51]^{\mathrm{c}}[55]^{\mathrm{o}}[46]^{\mathrm{o}}{ }^{\mathrm{c}}} \\
{[50]^{\mathrm{o}}}\end{array}$ \\
\hline Immune deviation & $\begin{array}{l}\text { Treg cells, Il-10, TGF-beta, Suppression of Th1 } \\
\text { activity }\end{array}$ & {$[75]^{\mathrm{C}}[76]^{\mathrm{o}}[77]^{\mathrm{o}}[78]^{\mathrm{o}}[79]^{\mathrm{o}}$} \\
\hline Sensitivity/inhibition & $\begin{array}{l}\text { Antirheumatics, vitamin D, bisphosphonates, } \\
\text { polyphenols, } \\
\text { Tamoxifen, tyrosine kinase-inhibitors }\end{array}$ & 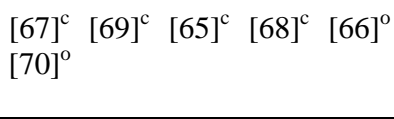 \\
\hline
\end{tabular}

$*^{\mathrm{O}}$ concerns osteoclasts, ${ }^{\mathrm{C}}$ concerns cancer

suggests a link between tumor cells and bone remodelling cells. Before we speculate about the possible causative factors for this connection, we will discuss the various common features and their specifity.

Concerning the phenotypic aspects of cancer development and bone remodelling we had to make a selection of features for this comparison. We chose noteworthy ones which can be classified as belonging to the key features of both cancer and osteoclasts. In some cases selection was undertaken arbitrarily. How specific are these features for both types of cells? There are probably no isolated features applicable only to these two cell types and not found elsewhere in other cells and tissues, but some are more prominent and are encountered in the same specific context in the cancer site as in the bone environment. This is true of the following aspects: the coupling of cancer cells with mesenchymal/stromal cells on the one hand and of osteoclast with mesenchymal osteoblasts on the other, the migrating and transmigrating capacities of cancer cells and preosteoclasts, their matrix-dissolving functions, their trafficking to bone (especially lung-, 
prostate-, breast- and renal cell carcinoma), the paracrine stimulatory effects of cancer cells on osteoclasts and vice versa, specific calcium signalling pathways, e. g. calcitonin-calcitonin receptor axis, sensitivity to antirheumatics and bisphosphonates, immune deviation and extreme plasticity of both cell lines.

The calcium signalling pathways seem to play an important role in cancer as well in bone remodelling. Vitamin D, osteocalcin, calcitonin, osteopontin and parathyroid hormone-related peptide are reviewed in this study. Various studies hint at their decisive role not just in bone metastases, but also in carcinogenesis and cancer procession.

Cancer cells and osteoclasts are inhibited by the same therapeutic substances. Antitumoral substances inhibit osteoclastogenesis, and antiosteoclastic substances such as bisphosphonates and antirheumatics inhibit cancer cells and may prevent carcinogenesis. Does this apply to physiological substances as well? Does the enhancement of bone-mass formation by a physiological substance such as calcitonin also imply an antitumoral effect? The studies are contradictory in this regard. In breast cancer calcitonin shows antitumoral activity, whereas in prostate cancer it enhances the malignity. Whether this can be explained by the different bone metastasis action - breast cancer cells act in a more bonelytic, and prostate cancer in a more boneblastic manner - must be left open.

The rest of the reviewed features are found more ubiquitously. This applies to the IGF-IGF-1-receptor axis, constitutive NFkappaB/Stat3 activation, neurogenesis and neuronal and hormonal dependency. Myeloid-derived inflammatory cells are characterized by these properties, whereas epithelial cells are not. Thus the inflammatory features are characteristic for the whole lineage of myeloid-derived cells and consequently likewise substantiate our conceptual approach.

So far we have not referred to the differences between the two cell types. Cancer cells proliferate and preosteoclasts fuse with each other to become mature multinucleated osteoclasts. In this aspect, the two cell types function in an opposite way. We may ask whether there is a common basis for these two opposite behaviours. The reduced membrane potential may be a prerequisite for fusion of preosteoclasts ${ }^{93}$ as well as for proliferation of cancer cells. ${ }^{94}$ Could it be that initiation of reduced membrane potential is directed into continuous proliferation in the case of cancer because the potential preosteoclast cannot fuse at the epithelial site, but intends to do so?

When the epithelium is wounded or otherwise disturbed, e.g. by hypoxia, inflammatory cells such as monocytes - and among them a fraction of potential preosteoclasts - are attracted to this site. ${ }^{95}$ The role of these potential preosteoclasts is unknown in this context and probably has to do with tissue repair. When their function is completed they may apoptose or re-enter circulation and perhaps migrate to the bone to fuse with their equals. As mature osteoclasts they remodel the bone in connection with osteoblasts. Compared to an inflammatory region, a cancer site attracts these specific monocytes even more. ${ }^{96}$ Why do the cancers attract potential osteoclasts to such an extent? Furthermore, they attract mesenchymal cells from the bone marrow as well, thus creating here the connecting environment between myeloid and mesenchymal cells, as is the case in the bone where both cell types remodel the bone.

Cancer cells show a cytokeratin scaffold, whereas preosteoclasts show a mesenchymal-like one. However, cancer cells can transform their scaffold into vimentin, a process named EMT (epithelial-mesenchymal transition). The opposite transformation is possible as well, the mesenchymal-epithelial transition. Do the preosteoclasts have the same plasticity? There are very few publications on this issue, but they hint in this direction. Hematopoietic lineage-committed bone marrow cells, to which the progenitors of preosteoclasts belong among others, can transdifferentiate into epithelial cells $^{89}$. We may further ask if cancer cells can transform themselves into osteoclasts. This is not the case. Cancer cells may however become multinucleated. When the prostate cancer cell line PC-3 and its xenograft in mice were exposed to polyethylene glycol, multinucleated cells were induced; however they later disappeared through apoptosis. The author suggests that the prostate cancer cells or their progenitor cells transformed into multinucleated giant cells and then apoptosed. ${ }^{97}$ In a more polymerized form, porous polyethylene has biomaterial properties that can be fixed to bone. Polyethylene-wear particles from joint implants induce the formation of foreign giant cells and osteoclast precursors within the granuloma, whereas bone particles of the same size and under the same conditions induce osteoclast differentiation. ${ }^{42}$ Polyethylene with its biomaterial properties exerts fusogenic properties on monocyte-lineage cells as well as on cancer cells. In another in-vitro study breast cancer cell lines showed bone resorbing activity, but they did not transform themselves into multinucleated osteoclasts in these experiments. ${ }^{98}$

In rare cases carcinomas may develop as a conjunction of pleomorphic and osteoclastic cells in the so-called giant cell carcinoma. Its incidence, e.g. in the pancreas is indicated from $2.1 \%$ to $12.8 \%$ in the literature. Its epithelial origin is discussed. ${ }^{99}$ 
Not all cancer cells metastasize to the bone. Cancer of the skin and of the gastro-intestinal tract, except rectum, seldom metastasize to the bone. One determinant of the site of metastasis is blood flow from the primary site. The liver may be a filter for carcinomas of the gastrointestinal tract, which seldom metastasize into the bone. It is not otherwise known why these primary cancer sites seldom metastasize to the skeleton.

Cancer cell stimulate the differentiation of preosteoclasts into osteoclasts, and their migration to the site of bone metastasis. ${ }^{80,100}$ If the cancer cells are considered as cells with many preosteoclast features and functions, this stimulation can be interpreted as a paracrine, or quasi-autocrine enhancement. They stimulate the cell line of which, according to our interpretation, they may form a part.

How cancer cells or their progenitors acquire some preosteoclastic traits or vice-versa, or how potential preosteoclasts may adopt cancer properties and traits, is obscure. Formulated as a simplified question, we can ask: Are cancer cells preosteoclasts disguised as epithelial cells, and converted from fusion with each other to proliferation? Proposed hypotheses to explain some aspects of these findings are: fusion of preosteoclasts with epithelial stem cells, hybridization, DNA transfer, the plasticity of stem cell of the preosteoclastic lineage, or metaplasia. ${ }^{101}$ The data reviewed in this paper tends to support the hypothesis that the plasticity of stem cells of preosteoclastic lineage may be implicated in carcinogenesis. There are various studies suggesting that tumor-initiating cells may be responsible for carcinogenesis and the maintenance of tumor growth. ${ }^{102}$ In most studies the tumor-initiating cells were identified as being hematopoietic stem cells and thus - among others - progenitors of the preosteoclastic lineage. ${ }^{103}$ These cells would have all the genetic prerequisites to differentiate into cancer cells with preosteoclastic traits. There is a second reason why we suggest that cancer cells emerge from the preosteoclastic lineage due to plasticity and the corresponding microenvironment. We already demonstrated that in the inner ear carcinogenesis does not arise although epithelial cells, lining the inner wall of the cochlea, are capable of proliferation and inflammatory processes. The unique feature in this area is however, that haematopoietic lineage can not develop into preosteoclastic and osteoclastic cells due to inhibitory decoy receptor osteoprotegerin present in this area suggesting that this missing process may prevent carcinogenesis in the inner ear. ${ }^{2}$

We did not review the common intracellular pathways specifically activated in preosteoclasts and cancer cells and we did not investigate in detail how the energy metabolism, especially lipid metabolism, is directed by bone cells and cancer cells in the same direction. This will be reserved for future publications.

This review may stimulate a new oncology research direction in future. It may also raise the question as to whether any antiosteoporotic measure - be it physical, nutritional or therapeutic -, might imply an antitumor activity. These concrete questions warrant further studies on the connection between bone remodeling and cancer.

Conflicting Interest: The author declares no conflict of interest.

\section{REFERENCES}

[1] Pawelek J, Chakraborty A, Lazova R, Yilmaz Y, Cooper D, Brash D, Handerson T: Co-opting macrophage traits in cancer progression: a consequence of tumor cell fusion? Contrib Microbiol 2006;13:138-155. PMid:16627963 http://dx.doi.org/10.1159/000092970

[2] Schramm HM: The role of the osteoimmune axis in the inflammation of the inner auditory ear and with regard to the putative anticarcinogenetic principle: part 2. Inflamm Allergy Drug Targets 2010;9(2):120-129.PMid:20402646

[3] Rucci N, Teti A: Osteomimicry: how tumor cells try to deceive the bone. Front Biosci (Schol Ed) 2010;2:907-915.

http://dx.doi.org/10.2741/S110

[4] Clezardin P, Teti A: Bone metastasis: pathogenesis and therapeutic implications. Clin Exp Metastasis 2007;24(8):599-608. http://dx.doi.org/10.1007/s10585-007-9112-8

[5] Huang WC, Xie Z, Konaka H, Sodek J, Zhau HE, Chung LW: Human osteocalcin and bone sialoprotein mediating osteomimicry of prostate cancer cells: role of cAMP-dependent protein kinase A signaling pathway. Cancer Res 2005;65(6):2303-2313. PMid:15781644

http://dx.doi.org/10.1158/0008-5472.CAN-04-3448

[6] Saltel F, Chabadel A, Bonnelye E, Jurdic P: Actin cytoskeletal organisation in osteoclasts: a model to decipher transmigration and matrix degradation. Eur J Cell Biol 2008;87(8-9):459-468. PMid:18294724 http://dx.doi.org/10.1016/j.ejcb.2008.01.001

[7] Parri M, Chiarugi P: Rac and Rho GTPases in cancer cell motility control. Cell Commun Signal 2010;8:23. PMid:20822528 PMCid:2941746 
http://dx.doi.org/10.1186/1478-811X-8-23

[8] Yu X, Huang Y, Collin-Osdoby P, Osdoby P: Stromal cell-derived factor-1 (SDF-1) recruits osteoclast precursors by inducing chemotaxis, matrix metalloproteinase-9 (MMP-9) activity, and collagen transmigration. J Bone Miner Res 2003;18(8):1404-18. PMid:12929930

http://dx.doi.org/10.1359/jbmr.2003.18.8.1404

[9] Egeblad M, Littlepage LE, Werb Z: The fibroblastic coconspirator in cancer progression. Cold Spring Harb Symp Quant Biol 2005;70:383-388. PMid:16869775 PMCid:2580828ｈttp://dx.doi.org/10.1101/sqb.2005.70.007

[10] Gazitt Y: Homing and mobilization of hematopoietic stem cells and hematopoietic cancer cells are mirror image processes, utilizing similar signaling pathways and occurring concurrently: circulating cancer cells constitute an ideal target for concurrent treatment with chemotherapy and antilineage-specific antibodies. Leukemia 2004;18(1):1-10. PMid:14574330 http://dx.doi.org/10.1038/sj.leu.2403173

[11] Dittmar T, Heyder C, Gloria-Maercker E, Hatzmann W, Zanker KS: Adhesion molecules and chemokines: the navigation system for circulating tumor (stem) cells to metastasize in an organ-specific manner. Clin Exp Metastasis 2008;25(1):11-32.

http://dx.doi.org/10.1007/s10585-007-9095-5

[12] Mishra P, Banerjee D, Ben-Baruch A: Chemokines at the crossroads of tumor-fibroblast interactions that promote malignancy. J Leukoc Biol 2010.

[13] Teicher BA, Fricker SP: CXCL12 (SDF-1)/CXCR4 pathway in cancer. Clin Cancer Res 2010;16(11):2927-2931. PMid:20484021 http://dx.doi.org/10.1158/1078-0432.CCR-09-2329

[14] Yadav VR, Sung B, Prasad S, Kannappan R, Cho SG, Liu M, Chaturvedi MM, Aggarwal BB: Celastrol suppresses invasion of colon and pancreatic cancer cells through the downregulation of expression of CXCR4 chemokine receptor. J Mol Med 2010.

[15] Kryczek I, Wei S, Keller E, Liu R, Zou W: Stroma-derived factor (SDF-1/CXCL12) and human tumor pathogenesis. Am J Physiol Cell Physiol 2007;292(3):C987-995. PMid:16943240 http://dx.doi.org/10.1152/ajpcell.00406.2006

[16] Fujisaki K, Tanabe N, Suzuki N, Kawato T, Takeichi O, Tsuzukibashi O, Makimura M, Ito K, Maeno M: Receptor activator of NF-kappaB ligand induces the expression of carbonic anhydrase II, cathepsin K, and matrix metalloproteinase-9 in osteoclast precursor RAW264.7 cells. Life Sci 2007;80(14):1311-1318. PMid:17306833 http://dx.doi.org/10.1016/j.lfs.2006.12.037

[17] Cordes C, Bartling B, Simm A, Afar D, Lautenschlager C, Hansen G, Silber RE, Burdach S, Hofmann HS: Simultaneous expression of Cathepsins $\mathrm{B}$ and $\mathrm{K}$ in pulmonary adenocarcinomas and squamous cell carcinomas predicts poor recurrence-free and overall survival. Lung Cancer 2009;64(1):79-85. PMid:18760860～http://dx.doi.org/10.1016/j.lungcan.2008.07.005

[18] Kleer CG, Bloushtain-Qimron N, Chen YH, Carrasco D, Hu M, Yao J, Kraeft SK, Collins LC, Sabel MS, Argani P, Gelman R, Schnitt SJ, Krop IE, Polyak K: Epithelial and stromal cathepsin K and CXCL14 expression in breast tumor progression. Clin Cancer Res 2008;14(17):5357-5367. PMid:18765527 PMCid:2630242

http://dx.doi.org/10.1158/1078-0432.CCR-08-0732

[19] Bagnoli F, Oliveira VM, Silva MA, Taromaru GC, Rinaldi JF, Aoki T: The interaction between aromatase, metalloproteinase 2,9 and cd44 in breast cancer. Rev Assoc Med Bras 2010;56(4):472-477. http://dx.doi.org/10.1590/S0104-42302010000400023

[20] Rose AA, Siegel PM: Emerging therapeutic targets in breast cancer bone metastasis. Future Oncol 2010;6(1):55-74.

PMid:20021209 http://dx.doi.org/10.2217/fon.09.138

[21] Powe D G VMJ, ZÃanker K S, habashy H O, Green A R, Ellis I O, Entschladen F: Beta-Blocker Drug Therapy Reduces Secondary Cancer Formation in Breast Cancer and Improves Cancer Sepcific Survival. Oncotarget 2010:1-11.

[22] Togari A: Adrenergic regulation of bone metabolism: possible involvement of sympathetic innervation of osteoblastic and osteoclastic cells. Microsc Res Tech 2002;58(2):77-84. PMid:12203706

http://dx.doi.org/10.1002/jemt.10121

[23] Togari A, Arai M, Kondo A: The role of the sympathetic nervous system in controlling bone metabolism. Expert Opin Ther Targets 2005;9(5):931-940. PMid:16185149 http://dx.doi.org/10.1517/14728222.9.5.931

[24] Togari A, Mogi M, Arai M, Yamamoto S, Koshihara Y: Expression of mRNA for axon guidance molecules, such as semaphorin-III, netrins and neurotrophins, in human osteoblasts and osteoclasts. Brain Res 2000;878(1-2):204-209.

http://dx.doi.org/10.1016/S0006-8993(00)02700-1

[25] Varner JA: Stem cells and neurogenesis in tumors. Prog Exp Tumor Res 2007;39:122-129. http://dx.doi.org/10.1159/000100072

[26] Liu YN, Liu Y, Lee HJ, Hsu YH, Chen JH: Activated androgen receptor downregulates E-cadherin gene expression and promotes tumor metastasis. Mol Cell Biol 2008;28(23):7096-7108. PMid:18794357ＰMCid:2593382ｈttp://dx.doi.org/10.1128/MCB.00449-08

[27] Fasco MJ, Hurteau GJ, Spivack SD: Gender-dependent expression of alpha and beta estrogen receptors in human nontumor and tumor lung tissue Mol Cell Endocrinol 2002;188(1-2):125-140. http://dx.doi.org/10.1016/S0303-7207(01)00750-X

[28] Olivo-Marston SE, Mechanic LE, Mollerup S, Bowman ED, Remaley AT, Forman MR, Skaug V, Zheng YL, Haugen A, Harris CC: Serum estrogen and tumor-positive estrogen receptor-alpha are strong prognostic classifiers of non-small-cell lung cancer survival in both men and women. Carcinogenesis 2010;31(10):1778-1786. PMid:20729390 http://dx.doi.org/10.1093/carcin/bgq156 
[29] Hong L, Sultana H, Paulius K, Zhang G: Steroid regulation of proliferation and osteogenic differentiation of bone marrow stromal cells: a gender difference. J Steroid Biochem Mol Biol 2009;114(3-5):180-185. PMid:19429449～PMCid:2682591

http://dx.doi.org/10.1016/j.jsbmb.2009.02.001

[30] Michael H, Harkonen PL, Kangas L, Vaananen HK, Hentunen TA: Differential effects of selective oestrogen receptor modulators (SERMs) tamoxifen, ospemifene and raloxifene on human osteoclasts in vitro. Br J Pharmacol 2007;151(3):384-395. PMid:17420779 PMCid:2013975

http://dx.doi.org/10.1038/sj.bjp.0707232

[31] Yakar S, Pennisi P, Kim CH, Zhao H, Toyoshima Y, Gavrilova O, LeRoith D: Studies involving the GH-IGF axis: Lessons from IGF-I and IGFI receptor gene targeting mouse models. J Endocrinol Invest 2005;28(5 Suppl):19-22.PMid:16114270

[32] Laron Z: The GH-IGF1 axis and longevity. The paradigm of IGF1 deficiency. Hormones (Athens) 2008;7(1):24-27.

[33] Shevah O, Laron Z: Patients with congenital deficiency of IGF-I seem protected from the development of malignancies: a preliminary report. Growth Horm IGF Res 2007;17(1):54-57. http://dx.doi.org/10.1016/j.ghir.2006.10.007

[34] Natsuizaka M, Ohashi S, Wong GS, Ahmadi A, Kalman RA, Budo D, Klein-Szanto AJ, Herlyn M, Diehl JA, Nakagawa H: Insulin-like growth factor-binding protein-3 promotes transforming growth factor-\{beta\}1-mediated epithelial-to-mesenchymal transition and motility in transformed human esophageal cells. Carcinogenesis 2010;31(8):1344-1353. PMid:20513670 PMCid:2915630

http://dx.doi.org/10.1093/carcin/bgq108

[35] Irie HY, Pearline RV, Grueneberg D, Hsia M, Ravichandran P, Kothari N, Natesan S, Brugge JS: Distinct roles of Akt1 and Akt2 in regulating cell migration and epithelial-mesenchymal transition. J Cell Biol 2005;171(6):1023-1034. PMid:16365168 PMCid:2171329 http://dx.doi.org/10.1083/jcb.200505087

[36] Wang Y, Nishida S, Sakata T, Elalieh HZ, Chang W, Halloran BP, Doty SB, Bikle DD: Insulin-like growth factor-I is essential for embryonic bone development. Endocrinology 2006;147(10):4753-4761. PMid:16857753

http://dx.doi.org/10.1210/en.2006-0196

[37] Wang Y, Nishida S, Elalieh HZ, Long RK, Halloran BP, Bikle DD: Role of IGF-I signaling in regulating osteoclastogenesis. J Bone Miner Res 2006;21(9):1350-1358. PMid:16939393 http://dx.doi.org/10.1359/jbmr.060610

[38] Lee JL, Wang MJ, Sudhir PR, Chen GD, Chi CW, Chen JY: Osteopontin promotes integrin activation through outside-in and inside-out mechanisms: OPN-CD44V interaction enhances survival in gastrointestinal cancer cells. Cancer Res 2007;67(5):2089-2097. PMid:17332338

http://dx.doi.org/10.1158/0008-5472.CAN-06-3625

[39] Samanna V, Wei H, Ego-Osuala D, Chellaiah MA: Alpha-V-dependent outside-in signaling is required for the regulation of CD44 surface expression, MMP-2 secretion, and cell migration by osteopontin in human melanoma cells. Exp Cell Res 2006;312(12):2214-2230. PMid:16631740 http://dx.doi.org/10.1016/j.yexcr.2006.03.022

[40] Fujikawa Y, Sabokbar A, Neale S, Athanasou NA: Human osteoclast formation and bone resorption by monocytes and synovial macrophages in rheumatoid arthritis. Ann Rheum Dis 1996;55(11):816-822. PMid:8976638ＰMCid:1010317 http://dx.doi.org/10.1136/ard.55.11.816

[41] Yamamoto Y, Yamamoto Y, Udagawa N, Okumura S, Mizoguchi T, Take I, Yamauchi H, Yamauchi H, Noguchi T, Takahashi N: Effects of calcitonin on the function of human osteoclast-like cells formed from CD14-positive monocytes. Cell Mol Biol (Noisy-le-grand) 2006;52(3):2531.

[42] Shen Z, Crotti TN, McHugh KP, Matsuzaki K, Gravallese EM, Bierbaum BE, Goldring SR: The role played by cell-substrate interactions in the pathogenesis of osteoclast-mediated peri-implant osteolysis. Arthritis Res Ther 2006;8(3):R70. http://dx.doi.org/10.1186/ar1938

[43] Han B, Nakamura M, Zhou G, Ishii A, Nakamura A, Bai Y, Mori I, Kakudo K: Calcitonin inhibits invasion of breast cancer cells: involvement of urokinase-type plasminogen activator (uPA) and uPA receptor. Int J Oncol 2006;28(4):807-814.PMid:16525628

[44] Shah GV, Thomas S, Muralidharan A, Liu Y, Hermonat PL, Williams J, Chaudhary J: Calcitonin promotes in vivo metastasis of prostate cancer cells by altering cell signaling, adhesion, and inflammatory pathways. Endocr Relat Cancer 2008;15(4):953-964. PMid:18784182

http://dx.doi.org/10.1677/ERC-08-0136

[45] Massfelder T, Lang H, Schordan E, Lindner V, Rothhut S, Welsch S, Simon-Assmann P, Barthelmebs M, Jacqmin D, Helwig JJ: Parathyroid hormone-related protein is an essential growth factor for human clear cell renal carcinoma and a target for the von Hippel-Lindau tumor suppressor gene. Cancer Res 2004;64(1):180-188. PMid:14729622～http://dx.doi.org/10.1158/0008-5472.CAN-03-1968

[46] Fiaschi-Taesch NM, Stewart AF: Minireview: parathyroid hormone-related protein as an intracrine factor--trafficking mechanisms and functional consequences. Endocrinology 2003;144(2):407-411. PMid:12538599ｈttp://dx.doi.org/10.1210/en.2002-220818

[47] Yamamura-Idei Y, Kitazawa S, Kitazawa R, Fujimori T, Chiba T, Maeda S: Parathyroid hormone-related protein in gastric cancers with heterotopic ossification. Cancer 1993;72(6):1849-1852.

http://dx.doi.org/10.1002/1097-0142(19930915)72:6<1849::AID-CNCR2820720610>3.0.CO;2-H

[48] Martin TJ: Osteoblast-derived PTHrP is a physiological regulator of bone formation. J Clin Invest 2005;115(9):2322-2324. PMid:16138187 PMCid:1193889 http://dx.doi.org/10.1172/JCI26239

[49] Sims NA, Gooi JH: Bone remodeling: Multiple cellular interactions required for coupling of bone formation and resorption. Semin Cell Dev Biol 2008;19(5):444-451. http://dx.doi.org/10.1016/j.semcdb.2008.07.016 
[50] Houpis CH, Tosios KI, Papavasileiou D, Christopoulos PG, Koutlas IG, Sklavounou A, Alexandridis C: Parathyroid hormone-related peptide (PTHrP), parathyroid hormone/parathyroid hormone-related peptide receptor 1 (PTHR1), and MSX1 protein are expressed in central and peripheral giant cell granulomas of the jaws. Oral Surg Oral Med Oral Pathol Oral Radiol Endod 2010;109(3):415-424. PMid:20060342

http://dx.doi.org/10.1016/j.tripleo.2009.09.026

[51] Kayed H, Bekasi S, Keleg S, Michalski CW, Giese T, Friess H, Kleeff J: BGLAP is expressed in pancreatic cancer cells and increases their growth and invasion. Mol Cancer 2007;6:83. PMid:18163903 PMCid:2245975 http://dx.doi.org/10.1186/1476-4598-6-83

[52] Gardner TA, Lee SJ, Lee SD, Li X, Shirakawa T, Kwon DD, Park RY, Ahn KY, Jung C: Differential expression of osteocalcin during the metastatic progression of prostate cancer. Oncol Rep 2009;21(4):903-908.PMid:19287987

[53] Salem AM, Zohny SF, Abd El-Wahab MM, Hamdy R: Predictive value of osteocalcin and beta-CrossLaps in metastatic breast cancer. Clin Biochem 2007;40(16-17):1201-1208. PMid:17889845ｈttp://dx.doi.org/10.1016/j.clinbiochem.2007.07.006

[54] Colucci S, Giannelli G, Grano M, Faccio R, Quaranta V, Zallone AZ: Human osteoclast-like cells selectively recognize laminin isoforms, an event that induces migration and activates Ca2+ mediated signals. J Cell Sci 1996;109 (Pt 6):1527-1535.PMid:8799839

[55] Fernandez-Real JM, Izquierdo M, Ortega F, Gorostiaga E, Gomez-Ambrosi J, Moreno-Navarrete JM, Fruhbeck G, Martinez C, Idoate F, Salvador J, Forga L, Ricart W, Ibanez J: The relationship of serum osteocalcin concentration to insulin secretion, sensitivity, and disposal with hypocaloric diet and resistance training. J Clin Endocrinol Metab 2009;94(1):237-245. http://dx.doi.org/10.1210/jc.2008-0270

[56] Olumi AF, Grossfeld GD, Hayward SW, Carroll PR, Tlsty TD, Cunha GR: Carcinoma-associated fibroblasts direct tumor progression of initiated human prostatic epithelium. Cancer Res 1999;59(19):5002-5011.PMid:10519415

[57] Santini D, Perrone G, Roato I, Godio L, Pantano F, Grasso D, Russo A, Vincenzi B, Elisabetta Fratto M, Sabbatini R, Pepa CD, Porta C, Del Greco A, Schiavon G, Berruti A, Tomasino RM, Papotti M, Papapietro N, Onetti Muda A, Denaro V, Tonini G: Expression pattern of receptor activator of NFkappaB (RANK) in a series of primary solid tumors and related bone metastases. J Cell Physiol 2010.

[58] Yoshimura A: Signal transduction of inflammatory cytokines and tumor development. Cancer Sci 2006;97(6):439-447. PMid:16734720 http://dx.doi.org/10.1111/j.1349-7006.2006.00197.x

[59] Jarnicki A, Putoczki T, Ernst M: Stat3: linking inflammation to epithelial cancer - more than a "gut" feeling? Cell Div 2010;5:14.PMid:20478049ＰMCid:2887830

[60] Idris AI, Krishnan M, Simic P, Landao-Bassonga E, Mollat P, Vukicevic S, Ralston SH: Small molecule inhibitors of IkappaB kinase signaling inhibit osteoclast formation in vitro and prevent ovariectomy-induced bone loss in vivo. Faseb J 2010;24(11):4545-4555. PMid:20647545 http://dx.doi.org/10.1096/fj.10-164095

[61] Duan L, de Vos P, Fan M, Ren Y: IkappaBalpha regulates Hes1 in osteoclast differentiation and resorption. Front Biosci (Elite Ed) 2010;2:10651072. http://dx.doi.org/10.2741/E164

[62] Li X, Kim KW, Cho ML, Ju JH, Kang CM, Oh HJ, Min JK, Lee SH, Park SH, Kim HY: IL-23 induces receptor activator of NF-kappaB ligand expression in fibroblast-like synoviocytes via STAT3 and NF-kappaB signal pathways. Immunol Lett 2010;127(2):100-107. PMid:19900478 http://dx.doi.org/10.1016/j.imlet.2009.10.012

[63] Mizutani K, Sud S, McGregor NA, Martinovski G, Rice BT, Craig MJ, Varsos ZS, Roca H, Pienta KJ: The chemokine CCL2 increases prostate tumor growth and bone metastasis through macrophage and osteoclast recruitment. Neoplasia 2009;11(11):1235-1242.PMid:19881959 PMCid:2767225

[64] Kim MS, Day CJ, Morrison NA: MCP-1 is induced by receptor activator of nuclear factor-\{kappa\}B ligand, promotes human osteoclast fusion, and rescues granulocyte macrophage colony-stimulating factor suppression of osteoclast formation. J Biol Chem 2005;280(16):16163-16169. PMid:15722361 http://dx.doi.org/10.1074/jbc.M412713200

[65] Fedirko V, Bostick RM, Goodman M, Flanders WD, Gross MD: Blood 25-hydroxyvitamin D3 concentrations and incident sporadic colorectal adenoma risk: a pooled case-control study. Am J Epidemiol;172(5):489-500. PMid:20650953 PMCid:3025635 http://dx.doi.org/10.1093/aje/kwq157

[66] Sakai S, Takaishi H, Matsuzaki K, Kaneko H, Furukawa M, Miyauchi Y, Shiraishi A, Saito K, Tanaka A, Taniguchi T, Suda T, Miyamoto T, Toyama Y: 1-Alpha, 25-dihydroxy vitamin D3 inhibits osteoclastogenesis through IFN-beta-dependent NFATc1 suppression. J Bone Miner Metab 2009;27(6):643-652. PMid:19449179ｈttp://dx.doi.org/10.1007/s00774-009-0084-4

[67] Axelsson H, Lonnroth C, Andersson M, Lundholm K: Mechanisms behind COX-1 and COX-2 inhibition of tumor growth in vivo. Int J Oncol 2010;37(5):1143-1152.PMid:20878062

[68] Neville-Webbe HL, Gnant M, Coleman RE: Potential anticancer properties of bisphosphonates. Semin Oncol 2010;37 Suppl 1:S53-65. PMid:20682373 http://dx.doi.org/10.1053/j.seminoncol.2010.06.008

[69] Fresco P, Borges F, Diniz C, Marques MP: New insights on the anticancer properties of dietary polyphenols. Med Res Rev 2006;26(6):747-766. PMid:16710860 http://dx.doi.org/10.1002/med.20060

[70] Wattel A, Kamel S, Prouillet C, Petit JP, Lorget F, Offord E, Brazier M: Flavonoid quercetin decreases osteoclastic differentiation induced by RANKL via a mechanism involving NF kappa B and AP-1. J Cell Biochem 2004;92(2):285-295. PMid:15108355 http://dx.doi.org/10.1002/jcb.20071

[71] Kim JM, Jeong D, Kang HK, Jung SY, Kang SS, Min BM: Osteoclast precursors display dynamic metabolic shifts toward accelerated glucose metabolism at an early stage of RANKL-stimulated osteoclast differentiation. Cell Physiol Biochem 2007;20(6):935-946. PMid:17982276 
http://dx.doi.org/10.1159/000110454

[72] Lopez-Lazaro M: The warburg effect: why and how do cancer cells activate glycolysis in the presence of oxygen? Anticancer Agents Med Chem 2008;8(3):305-312. http://dx.doi.org/10.2174/187152008783961932

[73] Gillies RJ, Robey I, Gatenby RA: Causes and consequences of increased glucose metabolism of cancers. J Nucl Med 2008;49 Suppl 2:24S-42S. PMid:18523064 http://dx.doi.org/10.2967/jnumed.107.047258

[74] Roiniotis J, Dinh H, Masendycz P, Turner A, Elsegood CL, Scholz GM, Hamilton JA: Hypoxia prolongs monocyte/macrophage survival and enhanced glycolysis is associated with their maturation under aerobic conditions. J Immunol 2009;182(12):7974-7981. PMid:19494322

http://dx.doi.org/10.4049/jimmunol.0804216

[75] Hanahan D, Weinberg RA: Hallmarks of cancer: the next generation. Cell 2011;144(5):646-674. PMid:21376230 http://dx.doi.org/10.1016/j.cell.2011.02.013

[76] Li H, Hong S, Qian J, Zheng Y, Yang J, Yi Q: Cross talk between the bone and immune systems: osteoclasts function as antigen-presenting cells and activate CD4+ and CD8+ T cells. Blood 2010;116(2):210-217. PMid:20304810 PMCid:2910608

http://dx.doi.org/10.1182/blood-2009-11-255026

[77] Kiesel JR, Buchwald ZS, Aurora R: Cross-presentation by osteoclasts induces FoxP3 in CD8+ T cells. J Immunol 2009;182(9):5477-5487. PMid:19380796 http://dx.doi.org/10.4049/jimmunol.0803897

[78] Grassi F, Manferdini C, Cattini L, Piacentini A, Gabusi E, Facchini A, Lisignoli G: T cell suppression by osteoclasts in vitro. J Cell Physiol 2010;226(4):982-990. PMid:20857429 http://dx.doi.org/10.1002/jcp.22411

[79] Fukada SY, Silva TA, Garlet GP, Rosa AL, da Silva JS, Cunha FQ: Factors involved in the T helper type 1 and type 2 cell commitment and osteoclast regulation in inflammatory apical diseases. Oral Microbiol Immunol 2009;24(1):25-31. PMid:19121066

http://dx.doi.org/10.1111/j.1399-302X.2008.00469.x

[80] Saltel F, Chabadel A, Zhao Y, Lafage-Proust MH, Clezardin P, Jurdic P, Bonnelye E: Transmigration: a new property of mature multinucleated osteoclasts. J Bone Miner Res 2006;21(12):1913-1923. PMid:17002556ｈttp://dx.doi.org/10.1359/jbmr.060821

[81] Helbig G, Christopherson KW, 2nd, Bhat-Nakshatri P, Kumar S, Kishimoto H, Miller KD, Broxmeyer HE, Nakshatri H: NF-kappaB promotes breast cancer cell migration and metastasis by inducing the expression of the chemokine receptor CXCR4. J Biol Chem 2003;278(24):2163121638. PMid:12690099 http://dx.doi.org/10.1074/jbc.M300609200

[82] Wright LM, Maloney W, Yu X, Kindle L, Collin-Osdoby P, Osdoby P: Stromal cell-derived factor-1 binding to its chemokine receptor CXCR4 on precursor cells promotes the chemotactic recruitment, development and survival of human osteoclasts. Bone 2005;36(5):840-853. PMid:15794931 http://dx.doi.org/10.1016/j.bone.2005.01.021

[83] Ferrara N: Role of myeloid cells in vascular endothelial growth factor-independent tumor angiogenesis. Curr Opin Hematol 2010;17(3):21924.PMid:20308892

[84] Wu Y, Yakar S, Zhao L, Hennighausen L, LeRoith D: Circulating insulin-like growth factor-I levels regulate colon cancer growth and metastasis. Cancer Res 2002;62(4):1030-1035.PMid:11861378

[85] Pratap J, Imbalzano KM, Underwood JM, Cohet N, Gokul K, Akech J, van Wijnen AJ, Stein JL, Imbalzano AN, Nickerson JA, Lian JB, Stein GS: Ectopic runx2 expression in mammary epithelial cells disrupts formation of normal acini structure: implications for breast cancer progression. Cancer Res 2009;69(17):6807-6814. PMid:19690135 PMCid:2742766

http://dx.doi.org/10.1158/0008-5472.CAN-09-1471

[86] Lee MS, Kim HS, Yeon JT, Choi SW, Chun CH, Kwak HB, Oh J: GM-CSF regulates fusion of mononuclear osteoclasts into bone-resorbing osteoclasts by activating the Ras/ERK pathway. J Immunol 2009;183(5):3390-3399. PMid:19641137

http://dx.doi.org/10.4049/jimmunol.0804314

[87] Lee SE, Chung WJ, Kwak HB, Chung CH, Kwack KB, Lee ZH, Kim HH: Tumor necrosis factor-alpha supports the survival of osteoclasts through the activation of Akt and ERK. J Biol Chem 2001;276(52):49343-49349. PMid:11675379

http://dx.doi.org/10.1074/jbc.M103642200

[88] Ohlsson C, Vandenput L: The role of estrogens for male bone health. Eur J Endocrinol 2009;160(6):883-889. PMid:19304870

http://dx.doi.org/10.1530/EJE-09-0118

[89] Fang TC, Otto WR, Rao J, Jeffery R, Hunt T, Alison MR, Cook HT, Wright NA, Poulsom R: Haematopoietic lineage-committed bone marrow cells, but not cloned cultured mesenchymal stem cells, contribute to regeneration of renal tubular epithelium after $\mathrm{HgCl} 2$-induced acute tubular injury. Cell Prolif 2008;41(4):575-591. PMid:18616694 http://dx.doi.org/10.1111/j.1365-2184.2008.00545.x

[90] Moore JC, Hilden K, Bentz JS, Pearson RK, Adler DG: Osteoclastic and pleomorphic giant cell tumors of the pancreas diagnosed via EUSguided FNA: unique clinical, endoscopic, and pathologic findings in a series of 5 patients. Gastrointest Endosc 2009;69(1):162-166. PMid:19111699 http://dx.doi.org/10.1016/j.gie.2008.08.025

[91] Mosnier JF, Balique JG: Pleomorphic giant cell carcinoma of the esophagus with coexpression of cytokeratin and vimentin and neuroendocrine differentiation. Arch Pathol Lab Med 2000;124(1):135-138.PMid:10629146 
[92] Deckard-Janatpour K, Kragel S, Teplitz RL, Min BH, Gumerlock PH, Frey CF, Ruebner BH: Tumors of the pancreas with osteoclast-like and pleomorphic giant cells: an immunohistochemical and ploidy study. Arch Pathol Lab Med 1998;122(3):266-272.PMid:9823867

[93] Hofmann G, Bernabei PA, Crociani O, Cherubini A, Guasti L, Pillozzi S, Lastraioli E, Polvani S, Bartolozzi B, Solazzo V, Gragnani L, Defilippi P, Rosati B, Wanke E, Olivotto M, Arcangeli A: HERG K+ channels activation during beta(1) integrin-mediated adhesion to fibronectin induces an up-regulation of alpha(v)beta(3) integrin in the preosteoclastic leukemia cell line FLG 29.1. J Biol Chem 2001;276(7):4923-4931. PMid:11080495 http://dx.doi.org/10.1074/jbc.M005682200

[94] Schramm HM: A unique intracellular, extracellular and transmembrane circulation of potassium ions in the auditory inner ear as an anticarcinogenic principle? Part 1. Inflamm Allergy Drug Targets 2010;9(2):109-119.PMid:20402647

[95] Xing L, Schwarz EM, Boyce BF: Osteoclast precursors, RANKL/RANK, and immunology. Immunol Rev 2005;208:19-29. PMid:16313338 http://dx.doi.org/10.1111/j.0105-2896.2005.00336.x

[96] Zimmermann HW, Seidler S, Nattermann J, Gassler N, Hellerbrand C, Zernecke A, Tischendorf JJ, Luedde T, Weiskirchen R, Trautwein C, Tacke F: Functional contribution of elevated circulating and hepatic non-classical CD14CD16 monocytes to inflammation and human liver fibrosis. PLoS One 2010;5(6):e11049. PMid:20548789 PMCid:2883575 http://dx.doi.org/10.1371/journal.pone.0011049

[97] Fukuta K, Kohri K, Fukuda H, Watanabe M, Sugimura T, Nakagama H: Induction of multinucleated cells and apoptosis in the PC-3 prostate cancer cell line by low concentrations of polyethylene glycol 1000. Cancer Sci 2008;99(5):1055-1062. PMid:18380794 http://dx.doi.org/10.1111/j.1349-7006.2008.00781.x

[98] Eilon G, Mundy GR: Direct resorption of bone by human breast cancer cells in vitro. Nature 1978;276(5689):726-728. PMid:732878 http://dx.doi.org/10.1038/276726a0

[99] Matsuzaki H, Schmied BM, Ulrich A, Batra SK, Pour PM: In vitro induction of giant cell tumors from cultured hamster islets treated with NNitrosobis(2-Oxopropyl)amine. Am J Pathol 2000;156(2):439-443. http://dx.doi.org/10.1016/S0002-9440(10)64748-7

[100] Guo Y, Tiedemann K, Khalil JA, Russo C, Siegel PM, Komarova SV: Osteoclast precursors acquire sensitivity to breast cancer derived factors early in differentiation. Bone 2008;43(2):386-393. http://dx.doi.org/10.1016/j.bone.2008.03.026

[101] Dittmar T, Schwitalla S, Seidel J, Haverkampf S, Reith G, Meyer-Staeckling S, Brandt BH, Niggemann B, Zanker KS: Characterization of hybrid cells derived from spontaneous fusion events between breast epithelial cells exhibiting stem-like characteristics and breast cancer cells. Clin Exp Metastasis 2010. http://dx.doi.org/10.1007/s10585-010-9359-3

[102] Chan KS, Espinosa I, Chao M, Wong D, Ailles L, Diehn M, Gill H, Presti J, Jr., Chang HY, van de Rijn M, Shortliffe L, Weissman IL: Identification, molecular characterization, clinical prognosis, and therapeutic targeting of human bladder tumor-initiating cells. Proc Natl Acad Sci U S A 2009;106(33):14016-14021. http://dx.doi.org/10.1073/pnas.0906549106

[103] Mizrak D, Brittan M, Alison MR: CD133: molecule of the moment. J Pathol 2008;214(1):3-9. http://dx.doi.org/10.1073/10.1002/path.2283 